\title{
The Effects of Information Technology Applications on Collaborating Capability in Achieving Organisational Competitive Advantages in Malaysia
}

\author{
Lew Sook Ling ${ }^{1}$, Ong Puay Tee ${ }^{2} \&$ Uchenna Cyril Eze ${ }^{3}$ \\ ${ }^{1}$ Faculty of Information Science and Technology, Multimedia University, Melaka, Malaysia \\ ${ }^{2}$ Faculty of Business, Multimedia University, Melaka, Malaysia \\ ${ }^{3}$ Division of Business and Management, United International College, Zhuhai, China \\ Correspondence: Lew Sook Ling, Faculty of Information Science and Technology, Multimedia University, Jalan \\ Ayer Keroh Lama, 75450 Melaka, Malaysia. Tel: 60-6252-3124. E-mail: sllew@mmu.edu.my
}

Received: March 29, 2013

Accepted: April 22, 2013

Online Published: June 17, 2013

doi:10.5539/ijbm.v8n13p1

URL: http://dx.doi.org/10.5539/ijbm.v8n13p1

\begin{abstract}
Emerging and developing countries, particularly in Asia, have seen relatively strong economic growth. With right information technology (IT) adoption, the strong growth would provide a great advantage in improving the potential of the growth of companies. This paper highlights information technology (IT) applications have moderating effects towards collaborating capability-organisational competitive advantage relationship based on empirical justifications of 295 Multimedia Super Corridor (MSC) Malaysia companies. These findings from Malaysia, a fast growing Asian country, would serve as guidelines to organisations in other emerging and developing countries on key IT application necessary for organisational competitive advantage. Findings reveal that there were nine IT applications that moderate the collaborating capability-E-Mail, Content Management, Decision Support System, Knowledge Base/Repository, Document Management, Search Engine, Website Content, Intranet and Internet Access. The contributions to research and practice including suggestions for future studies are discussed.
\end{abstract}

Keywords: collaborating capability, competitive advantage, IT applications, Malaysia

\section{Introduction}

Malaysia, a highly open economy with gross national income of USD7900 per capita is a leading exporter of electrical appliances, electronic parts and components, palm oil, and natural gas (World Bank, 2012). Recently, it gains five ranks to reach 21st position in the Global Competitiveness Index (GCI) 2011-2012, which places among the world's most developed countries, behind Singapore (world 2nd) and Hong Kong (world 11th) in Asia (Sala-I-Martin, Bilbao-Osorio, Blanke, Hanouz, \& Geiger, 2011).

With a progressive economy, Malaysia needs a new level of workforce who can work effectively across national and cultural boundaries so as to achieve sustainable organisational competitive advantage. Among the efforts to ease the borderless communications are to invest in appropriate information technology (IT) applications. Therefore, right foci on IT applications are imperative for organisations to be competitive in order to catch up with the advanced economies due to limited capital and increased competitions of globalisation.

This paper begins with research background and issues, followed by positioning of collaborating capability of information infrastructure capability on organisational competitive advantage. The conceptual framework is underpinned by Organisational Information Processing Theory (Galbraith, 1973). Collaborating capability was proven as an information infrastructure capability on organisational competitive advantage. The framework then incorporated IT applications as moderators using data from 295 Multimedia Super Corridor companies in Malaysia (MSC Malaysia companies). Finally, research implications, contributions, limitations and recommendations are discussed.

\section{Background and Issues}

Today's dynamic and globalised environment has compelled businesses to stay connected in a social web of networking in order to reap competitive advantage. One way of achieving this is to exploit the appropriate 
knowledge-and-technology resources (Bhatt, Emdad, Roberts, \& Grover, 2010; Chang \& Chuang, 2011; Lim, Stratopoulos \& Wirjanto, 2012). Among the initiatives undertaken by Malaysia in becoming knowledge-and-technology nation is the development of Multimedia Super Corridor (MSC) project which was conceptualised in 1996. The project was modeled after Silicon Valley, which would offer the best of first-world knowledge and information technology (IT) infrastructure, at developing-nation costs (MDEC, 1996-2008). This is also an initiative designed to help Malaysia leapfrog into a developed nation by 2020, which is also in tandem with the nation's Economic Transformation Programme (ETP) and Vision 2020 drive (Economic Planning Unit [EPU], 2012).

Substantial improvement was seen among the MSC Malaysia companies with competitive advantage in the latest surveys, MSC Malaysia Annual Industry 2010 and 2011, conducted online from $1^{\text {st }}$ January 2011 until 11th February 2011 and from 30th January 2012 until 15th February 2012 respectively. Quantum leap of total sales to RM31.73 billion was achieved in 2011, up by $162 \%$ from RM12.11 billion achieved in 2006. The remarkable increase of export sales also showed the ability of MSC Malaysia companies to penetrate markets globally. Since the establishment of the MSC Malaysia project has certainly proven to be fruitful in facilitating the growth of the knowledge-and-technology industries, studies on MSC Malaysia companies would be beneficial as it will help Malaysian industry to achieve advancement in terms of knowledge and technology.

However, there are only limited IT capability-organisational competitive advantage studies, specifically in the emerging countries. Studies that have been done in the Western countries (Bhatt, et al., 2010; Burca, Fynes, \& Brannick, 2006; Paul, 2008) or Asian countries such as Japan (Nonaka, 1994), Korea (Kim, 2001), Taiwan (Chang \& Chuang, 2011) and Hong Kong (Ngai \& Chan, 2005), cannot be generalised to Malaysian context due to differences in economies, cultures and business customs.

Past researches have described positive impacts of IT capability on competitive advantage (Chang \& Chuang, 2011; Lim et al., 2012; Paul, 2008). However, none of them rank the effectiveness of IT applications with the fact that not all the IT components contributed to productive outputs (Burca, et al., 2006; Dehning \& Stratopoulos, 2003; Kim, 2001).

Moreover, organisations in Malaysia are facing difficulties to obtain the appropriate IT applications. This is not only due to the limited knowledge from past research, but also due to the confronting IT issues and unique challenges related to the conditions of operating within a developing nation. Hence, this paper argues that if right relationships of IT applications for collaborating capability are identified, emerging countries organisations can optimise their organisational competitive advantages with existing resources and successfully catch up with their counterparts in advanced economies.

\section{Theoretical Context and Hypotheses}

\subsection{Collaborating Capability-Competitive Advantage Model}

Galbraith (1973) developed the Organisational Information Processing Theory (OIPT) and identified three important concepts: information processing needs, information processing capability and the information fit to obtain optimal performance. The concern of OIPT includes organisational processing capacity and performance. Organisations need quality information to cope with uncertainties. Uncertainty stems from missing required information and a specified task cannot be performed without the information (Galbraith, 1973, 1974; Premkumar, Ramamurthy, \& Saunders, 2005). Therefore, right amount and quality of information are required in confronting environmental uncertainties.

The theoretical research framework in this paper was underpinned by Organisational Information Processing Theory (OIPT) (Galbraith, 1973). Information processing needs and information processing capability are essential to obtain optimal performance. The theory advocates that organisations need quality information to cope with environmental uncertainty and improve their decision-making. Over the years, many studies have been successfully drawn from OIPT (Andres \& Zmud, 2001; B. L. Cooper, Watson, Wixom, \& Goodhue, 2000; Cuijpers, Guenter, \& Hussinger, 2011). Therefore, the concern of OIPT includes organisational capability and effectiveness from the complexity and dynamism of the environment. For this reason, collaborating capability is considered as an organisational capability, while organisational competitive advantage as effectiveness.

A study of German automotive supply chain has confirmed the role collaboration capability in organisational performance. It highlights the positive impact of quality of information on information-sharing and collaborative performance and encourages the organisations to collaborate together and share information (Wiengarten, Humphreys, Cao, Fynes, \& McKittrick, 2010). In view of the globalisation of business, individuals should be connected regardless of where they are from. Collaborating capability ensures performing a task of joint or 
shared efforts by two or more collaborators (Minkyun, 2010). Therefore, in this study, collaborating capability refers to the ability of "linking individuals so that they can work together".

The ultimate goal in business is to achieve organisational competitive advantage. Porter (1985) defines competitive advantage is the ability to attain a differentiation position of relative advantage. This concept was later scrutinised by Leonard-Barton (1995) who describes core capabilities form competitive advantage. Prior (2006) suggests competitive advantage is gained by exploiting access to "resources". The concepts mainly focused on core capabilities and resources as sources to maintain and improve its competitive position in the market. Therefore, in this research, collaborating capability is considered as the "resources" in this research to perform to attain a differentiation position among competitors.

Knowledge is operationalised as a processed resource and capability (Alavi \& Leidner, 2001; Benbya, Passiante, \& Aissa Belbaly, 2004; Davenport \& Prusak, 2000), the key element for an organisation to achieve competitive advantage is to possess collaborating capability. Hence, in this context of research, to obtain organisational competitive advantage, the ICT applications used in an organisation are based on its collaborating capability to obtain organisational competitive advantage.

Many scholars noted that collaboration is an enabler of other organisational capability, which constitutes to sustainable competitive advantage (Gabler, 1981; Grant, 1998; Michalisn, Smith, \& Kline, 1997). For instance, strategy-consulting organisations such as Bain, Boston Consulting Group and McKinsey have developed and effectively used IT applications to enhance dialogue among individuals. Common services are also needed to link people (collaborating capability) to work better. The moderate correlation suggests that organisations need common services such as IT planning, training, education, customer service and support to ensure mutual efforts by two or more individuals in order to perform task (Kim, 2001).

For instance, with instantaneous access to knowledge resources, FedEx's employees can easily interact across time zones, political borders, business divisions, and organisational hierarchy levels in a real-time online mode, thereby facilitating instantaneous exchange of knowledge while effectively transacting the organisational core business functions (Rao, Navoth, \& Horwitch, 1999).

Based on these arguments, the following hypothesis is outlined:

\section{H1: The more collaborating capability available, the higher organisational competitive advantage achieved.}

\subsection{IT Applications as Moderator}

Collaborating tools are central to organisational competitive advantage. Common collaborating tools include email, SMS, wikis, blogs, instant messaging, discussion groups, project workspaces, bulletin boards, task lists, calendars, document sharing and corporate portals (Christopher, 2006). For instance, when registered members access to corporate portals to give organisations a shared platform for online collaborators, the shared platform also serves as a natural forum for the collaborators (Benbya, et al., 2004). Decision support systems were developed to enhance collaborative group work between geographically dispersed professionals. Examples of the collaboration tools in the markets are Lotus Notes, Network Delivery Knowledge, and Fulcrum Knowledge Network (Meso \& Smith, 2000). As the business environment is dynamic, IT vendors are developing the tools in this dynamic space. In view of globalisation of business, people should be connected regardless of their physical locations.

The importance of IT applications for organisational competitive advantage was well recognised by many scholars over the years (Chang \& Chuang, 2011; Lim, et al., 2012; Paul, 2008; Qi, Lan, \& Guo, 2008; Wang, Klein, \& Jiang, 2007). They were seeking to have better understanding on the impact of IT on organisational capability on organisational competitive advantage. Wang, Klein and Jiang (2007) found that IT support indirectly benefits manufacturing organisations. The link indicates organisations must carefully align the IT support to strategic needs. A study carried out by Paul (2008) further revealed the relationship of IT perspective on business process agility. Both managerial and technical IT capabilities are proven have positive impact on organisational competitive advantage. Consequently, an empirical model was developed by Qi, Lan and Guo (2008) to test IT capability. The results showed positive impacts of IT capabilities on organisational competitive advantage. In summary, previous studies indicated mixed support for the hypothesis that IT applications have a direct effect on organisational competitive advantage. Instead, we posit that the relationship between collaborating capability and competitive advantage is contingent upon the extent of IT applications. In other words:

\section{H2: IT applications moderate the collaborating capability-competitive advantage relationship.}

As a result of this conceptualisation, the proposed research framework is depicted Figure 1. 


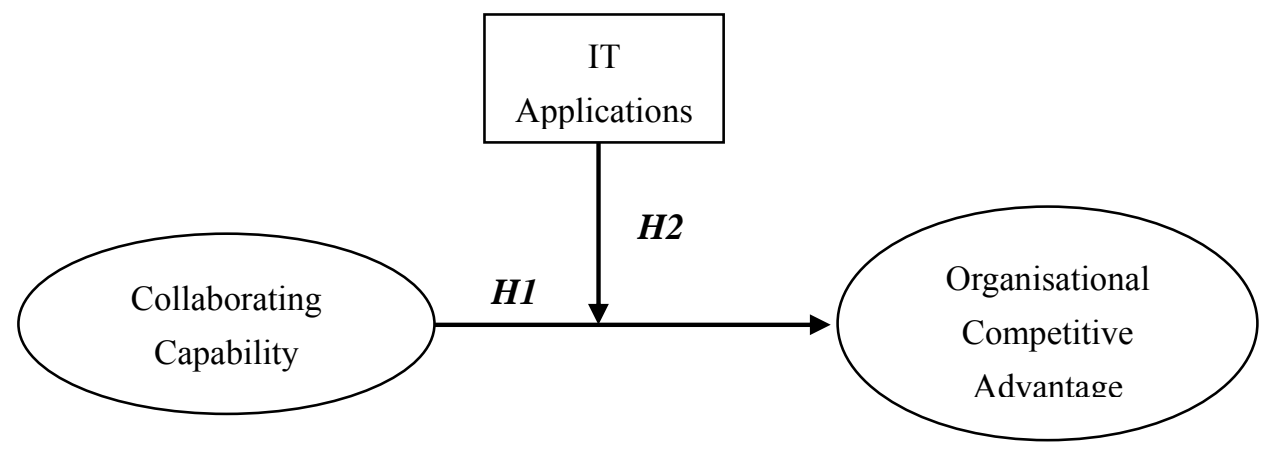

Figure 1. Conceptual framework

\section{Research Method}

We derived primary data from a set of survey questionnaire which was based on relevant prior studies, pilot testing and experts' reviews. Wording, planning and general appearance of the questionnaire were the three important issues should be focused on in questionnaire design (Sekaran, 2003). Design principles were identified and incorporated into the questionnaire to minimise biases (Czaja \& Blair, 1996; Salant \& Dillman, 1994). Hence, the questionnaire was developed, reviewed and tested prior to final dissemination to ensure the questions were understood by the respondents and there were no problems with the wording or measurement (Sekaran, 2003). A selected group of 50 middle managers of MSC Malaysia companies were pilot tested from May to June 2008. The returned rate was $76 \%$ totaling 38 sets. This met the minimum requirement of 25 (D. R. Cooper \& Schindler, 2006). Hence, content validity was verified and all the items that comprised the respective independent variables encompassed all of the main characteristics. Thus, the independent variables possessed a satisfactory degree of content validity. The industry and academic experts in KM also assessed and reviewed the questionnaire for content validity. After reviewing the pilot results and experts' reviews, the questionnaire items were refined and reformatted. Development of the dependent variable and moderating variable scales was also based on the definitions of the constructs provided by the extensive theoretical literature, so that these scales also possessed satisfactory levels of content validity.

The questionnaire used a five-point Likert scale ranging from 1-strongly disagree to 5-strongly agree to measure the indicator items. The questionnaire consisted of 5-item collaborating scale. The 5 items were adapted from prior relevant studies (Benbya, et al., 2004; Christopher, 2006; Kim, 2001; Meso \& Smith, 2000). Besides, there was an 18-item competitive advantage scale. From the 18 items, 14 (CA1 to CA14) were adapted from Bixler's (2000) study which described the organisational competitive advantage. Four additional questions were added in the context of responsiveness and flexibility (CA15) (Bhatt, et al., 2010; Chang \& Chuang, 2011; Paul, 2008; Wang, et al., 2007), products/services quality (CA16) (Nilsson, Johnson, \& Gustafsson, 2001; Reed, Lemak, \& Mero, 2000), product development life cycle (CA17) (Alting \& Jøgensen, 1993; Dunk, 2004)and decision making process (CA18) (Perera, 2012; Tseng, 2010) due to the unavailability in Bixler's study. Table 1 shows the list of items used.

Table 1. List of items used

\begin{tabular}{lll}
\hline \multicolumn{1}{c}{ Variable } & \multicolumn{1}{c}{ Item } & Description \\
\hline $\begin{array}{l}\text { Collaborating } \\
\text { Capability }\end{array}$ & Provide multimedia operations and development (i.e., video conferencing). \\
& C2 & Provide a common system for document management. \\
& C3 & Provide a common system for members of other work groups within an organisation. \\
& C4 & Provide electronic support for members of other work groups within an organisation. \\
& C5 & Develop a common system development environment. \\
\hline Competitive & CA1 & Stimulation and motivation of employees. \\
Advantage & CA2 & Formalised knowledge transfer system (Best practices, lessons learned). \\
& CA3 & Better on-the-job training for employees. \\
\hline
\end{tabular}




\begin{tabular}{ll}
\hline CA4 & Enhanced enterprise innovation and creativity. \\
CA5 & Improved overall enterprise performance. \\
CA7 & Enhanced client relations - better client interaction. \\
CA8 & Improved employee retention. \\
CA9 & Improved ability to sustain a competitive advantage. \\
CA10 & Enhanced transfer of knowledge from one employee to another. \\
CA11 & Means to identify industry best practices. \\
CA12 & Better methods for enterprise-wide problem solving. \\
CA13 & Enhanced business development and the creation of enterprise opportunities. \\
CA14 & Enhanced and streamlined internal administrative processes. \\
CA15 & Improved responsiveness and flexibility. \\
CA16 & Improved products/services quality. \\
CA17 & Improved product development life cycle. \\
CA18 & Expedite the decision making process. \\
\hline
\end{tabular}

Six hundred participants were selected from a total of two thousand and six MSC Malaysia organisations (www.mscmalaysia.com.my) based on a cross-sectional design and simple random sampling. The six hundred managers were contacted using emails and follow-up phone calls from July 2008 to February 2009. Three hundred and two questionnaires (50.3\%) were returned by the respondents. Listwise deletion of cases is used to treat the missing data; leaving two hundred and ninety five questionnaires (49.2\%) for analysis.

\section{Data Analysis and Findings}

We used listwise deletion of cases to treat the missing data (Hair, Black, Babin, \& Anderson, 2010), leaving 295 (49.2\%) questionnaires for analysis. We used Descriptive Statistical Analysis and Structural Equation Modeling (SEM) to analyse the data. Analysis of Moment Structures (AMOS) version 16.0 was used to examine the relationships among the variables/constructs in the theoretical framework (Hair, et al., 2010).

\subsection{Internal Consistency Reliabilities}

Testing for the internal consistency reliability of data was accomplished by obtaining the Cronbach's coefficient alpha of the measures (Sekaran, 2003). The alpha values were above the minimum cut-off alpha measure, 0.50 (Kline, 2005, 2009) as shown in Table 2. The alpha values indicated high consistency in the respondents' answers.

Table 2. Cronbach's alpha for the main constructs

Collaborating Capability

$$
0.62
$$

Competitive Advantage

$$
0.91
$$

\subsection{Demographic Profile}

The respondents consisted of 217 males (73.6\%) and 78 females (26.4). The respondents were categorised by age and the highest groups were 26-30 (41.7\%) and 31-35 (28.1\%). Department heads formed the largest position group $(85.8 \%)$ followed by section head $(13.6 \%)$. Most of the respondents were from IT department (34.2\%) and most of them were in the position for 1-5 years (69.5\%). University (Bachelor Degree) category, with $283(95.9 \%)$ respondents, had the highest percentage in terms of qualifications.

\subsection{Confirmatory Factor Analysis (CFA)/Final Measurement Model}

Confirmatory factor analysis (CFA) was used to validate the scales for the measurement of specific constructs and it played confirmatory role in which the researcher has complete control over the specification of the indicators for each construct (Hair, et al., 2010). Therefore, the use of CFA is to either "confirm" or "reject" the 
perceived theory.

\subsection{Guidelines for Establishing Acceptable and Unacceptable Fit}

Several guidelines were adhered to determine the acceptability of fit. In addition to the Model Chi-square $\left(X^{2}\right)$ value (Bollen, 1989) and the associated Degree of Freedom (DF), at least one incremental index and one absolute index needed to be reported (Hair, et al., 2010). Examples for incremental indices are Goodness of Fit Index (GFI) and Adjusted Goodness of Fit Index (AGFI) and absolute indices are Goodness of Fit Index (GFI) (Joreskog \& Sorbom, 1996) and Relative $X^{2} /$ Degree of Freedom (DF) (CMIN/DF) (Niels, 2008). Table 3 displays the measures of model fit indices and their acceptable levels used in this study.

Table 3. Selected model fit indices and acceptable levels

\begin{tabular}{|c|c|c|c|c|}
\hline Name & Description & Acceptable Level & Authors & Type \\
\hline$X^{2}$ and $X^{2} / \mathrm{DF}$ & $\begin{array}{l}\text { Lower value indicates better } \\
\text { fit. }\end{array}$ & $\begin{array}{l}p \text {-value below } 0.05 \\
X^{2} / \mathrm{DF} \text { below } 5.0\end{array}$ & $\begin{array}{l}\text { Bollen, 1989, Hair et al., } \\
\text { 2010, Kline, } 2005\end{array}$ & Absolute Fit \\
\hline CFI & $\begin{array}{l}\text { Higher value indicates better } \\
\text { fit. }\end{array}$ & Above 0.90 & Hair et al., 2010 & Incremental Fit \\
\hline RMSEA & $\begin{array}{l}\text { Lower value indicates better } \\
\text { fit. }\end{array}$ & 0.08 & Hair et al., 2010 & $\begin{array}{l}\text { Non-central } X^{2} \\
\text { Distribution }\end{array}$ \\
\hline GFI & $\begin{array}{l}\text { Higher value indicates better } \\
\text { fit. Value can range between } \\
0 \text { to } 1 .\end{array}$ & Above 0.90 & $\begin{array}{l}\text { Hair et al., 2010, Joreskog and } \\
\text { Sorbom, } 1996\end{array}$ & Absolute Fit \\
\hline AGFI & $\begin{array}{l}\text { Value can fall outside of } \\
\text { range } 0-0.10\end{array}$ & Values close to 0.80 & Joreskog and Sorbom, 1996 & Parsimony Fit \\
\hline
\end{tabular}

Revision of measurement model was done in order to obtain the final measurement model/Confirmatory Factor Analysis (CFA). Each of the offending indicator items was deleted one at a time from the initial model (23 indicator items-5-item capabilities and 18-item competitive advantage). Offending indicators, C4, C5, CA1 to CA8, CA10 to CA14, CA16 and CA18 were dropped due to the poor fit index effect based on the criteria suggested by literature (Table 3).

\subsection{Reliability and Validity Analysis}

Unstandardised loadings provided directionality and statistical significance, whereas standardised loadings were examined to confirm reliability and validity of constructs. Table 4 reports the unstandardised loadings, standardised loadings, composite reliability and Average Variance Extracted (AVE). All items have statistically significant with predicted direction. All the items have high loadings $(>0.50)$ and significant $(\mathrm{p}<0.001)$ as suggested value 0.50 (Hair, et al., 2010). In addition, the rule of thumb: each construct is indicated by at least three indicator items and above the acceptance level of model fit indices were observed. Composite Reliability $\left(\mathrm{R}^{2}\right)$ is calculated by dividing the sum of standardised loading squared by the sum of standardised loading plus the sum of measurement error (Hair, et al., 2010). All the $\mathrm{R}^{2}$ values were greater than 0.70 to confirm the convergent validity (Kline, 2005, 2009). Subsequently, construct reliability was confirmed by AVE greater than 0.50 (Hair, et al., 2010). Discriminant validity was confirmed by comparing if the square root of AVE of each construct is greater than the correlation between factors (Hair, et al., 2010). As shown in Table 5, all correlation coefficients were lower than the square root of AVE. Therefore, a strong evidence of discriminant validity was provided. 
Table 4. Reliability and validity coefficients

\begin{tabular}{|c|c|c|c|c|}
\hline Construct/ Indicators & Unstandardised Loadings & $\begin{array}{c}\text { Standardised } \\
\text { Loadings }>0.50^{\mathrm{a}}\end{array}$ & $\begin{array}{c}\text { Composite Reliability } \\
\mathrm{R}^{2}>0.70^{\mathrm{a}} \\
\end{array}$ & $\begin{array}{l}\text { Average Variance } \\
\text { Extracted }>0.50^{\mathrm{a}}\end{array}$ \\
\hline \multicolumn{5}{|l|}{ Collaborating } \\
\hline $\mathrm{C} 1$ & 1.00 & $0.74^{* * *}$ & 0.75 & 0.51 \\
\hline $\mathrm{C} 2$ & $0.98 * * *$ & $0.66^{* * *}$ & & \\
\hline $\mathrm{C} 3$ & $0.79 * * *$ & $0.56^{* * *}$ & & \\
\hline \multicolumn{5}{|l|}{ Competitive Advantage } \\
\hline CA9 & 1.00 & $0.91 * * *$ & 0.93 & 0.82 \\
\hline CA15 & $0.97 * * *$ & $0.86^{* * *}$ & & \\
\hline CA17 & $0.87 * * *$ & $0.79^{* * *}$ & & \\
\hline
\end{tabular}

Note: ${ }^{a}$ Recommended value. ${ }^{* * *} \mathrm{p}<0.001$.

Table 5. Inter constructs correlation

\begin{tabular}{ccc}
\hline & Competitive Advantage & Collaborating Capability \\
\hline Collaborating Capability & 0.22 & 0.71 \\
Competitive Advantage & 0.91 & \\
\hline
\end{tabular}

Note: Diagonals represent the square root of AVE and the 0.22 is the factor correlation.

Having determined the reliability and validity, the final measurement model was confirmed. Structural model was developed and assessed next to form the structural relationships. The research model is presented in Figure 2 with acceptable fit indices: $X^{2}=10.15, X^{2} / D F=1.269,(\leq 5.0), G F I=0.997(>0.90), R M S E A=0.030(\leq 0.08)$, Confidence Interval (CI) of RMSEA $=0.000, C F I=0.989(>0.90), A G F I=0.970(\geq 0.80)$. Collaborating capability-competitive advantage structural path estimate is supported $(\mathrm{H} 1)$. There are identical model fits of the final measurement model and the structural model. Hence, consistency of structural relationships with the theoretical expectation is achieved (Hair, et al., 2010).

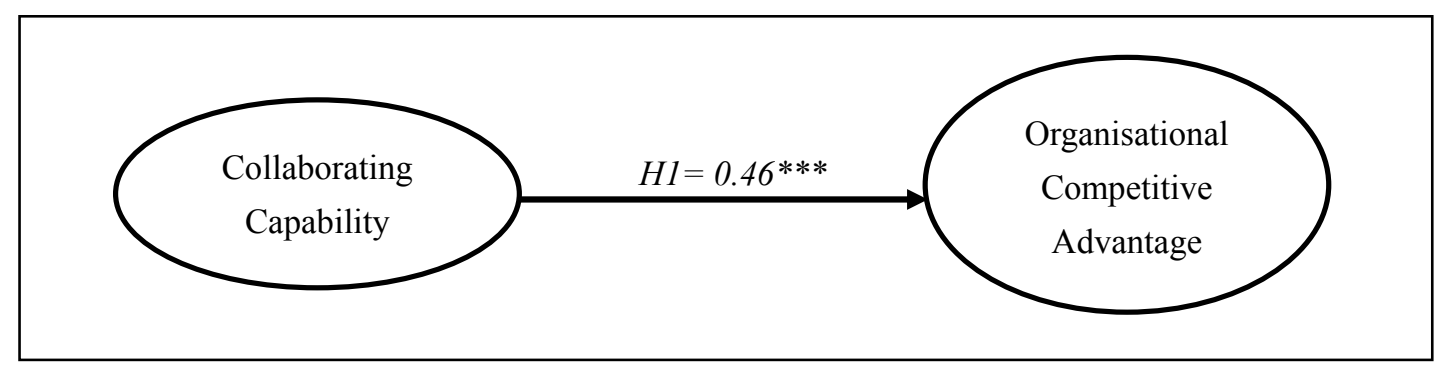

Figure 2. The research model and its related hypotheses

Note: Indicators and error variance terms of each indicator are omitted from the diagram for the sake of simplicity; ${ }^{* * *} \mathrm{p}<0.001$.

\subsection{Moderating Effects-IT Applications}

Types of IT application were tested as moderating variable. The top ten IT applications of the surveyed organisations are highlighted in Table 6. A list of common IT applications is presented in Table 6. 
Table 6. Common IT applications

\begin{tabular}{|c|c|c|c|}
\hline & IT Applications & Number $\mathrm{N}=295$ & Percentage \\
\hline 1 & E-mail System & 188 & 63.7 \\
\hline 2 & Content Management & 147 & 49.8 \\
\hline 3 & Decision Support System & 147 & 49.8 \\
\hline 4 & Knowledge Base / Knowledge Repository & 143 & 48.5 \\
\hline 5 & Document Management & 139 & 47.1 \\
\hline 6 & Search Engine & 136 & 46.1 \\
\hline 7 & Website Content Management & 128 & 43.4 \\
\hline 8 & Intranet & 123 & 41.7 \\
\hline 9 & Internet Access & 123 & 41.7 \\
\hline 10 & Workflow Systems & 110 & 37.3 \\
\hline 11 & Data Mining & 102 & 34.6 \\
\hline 12 & Relational Database & 94 & 31.9 \\
\hline 13 & Data Warehouse & 88 & 29.8 \\
\hline 14 & Video Conferencing & 75 & 25.4 \\
\hline 15 & Groupware & 72 & 24.4 \\
\hline 16 & Object Database & 52 & 17.6 \\
\hline 17 & Expert System & 47 & 15.9 \\
\hline 18 & Intelligent Agent & 29 & 9.8 \\
\hline 19 & Directories of Experts & 23 & 7.8 \\
\hline 20 & Others & 18 & 6.1 \\
\hline 21 & CBR (Case-based reasoning) & 12 & 4.1 \\
\hline 22 & Neural Network & 12 & 4.1 \\
\hline
\end{tabular}

The results are supported by previous studies which indicated that the most frequently utilised types of IT applications include content management systems, document management systems, data warehousing systems and data mining systems (Alavi \& Leidner, 2001; Meso \& Smith, 2000; Ngai \& Chan, 2005).

\subsection{Multiple Group Analysis of Structural Equation Modelling (SEM)}

Multiple group analysis is used to test if the measurement is the same for both groups which designed to run on two separate two-group analyses, first with no constraints and then again with the constraint that the loadings for the indicator variables. If the goodness of fit of the constrained model is worse than that for the corresponding unconstrained model, then the researcher concludes that model direct effects differ by group (Garson, 1998). The moderation is supported if the fit of the second model is significantly worst (Hair, et al., 2010). Furthermore, the hypothesis of moderation effect is supported when the value of the difference in $X^{2}$ exceeds the 0.05 critical value (Burca et al., 2006).

Table 7 displays model fits of unconstrained model and constrained model and value of model differences of nine IT applications which supported as moderators. The model fits of the unconstrained model are better than the constrained model.

Table 7. IT applications as moderators

\begin{tabular}{|c|c|c|c|c|c|c|}
\hline Model Characteristic & Model Fit & E-Mail & $\begin{array}{l}\text { Content } \\
\text { Management }\end{array}$ & $\begin{array}{l}\text { Decision } \\
\text { Support } \\
\text { System } \\
\end{array}$ & $\begin{array}{l}\text { Knowledge } \\
\text { Base/Repository }\end{array}$ & $\begin{array}{l}\text { Document } \\
\text { Management }\end{array}$ \\
\hline Unconstrained Group & $X^{2}$ & 20.85 & 46.85 & 27.89 & 42.85 & 19.39 \\
\hline \multirow[t]{3}{*}{ Model } & $\mathrm{DF}$ & 16 & 16 & 16 & 16 & 16 \\
\hline & CFI & 0.99 & 0.96 & 0.98 & 0.96 & 1.000 \\
\hline & RMSEA & 0.03 & 0.08 & 0.05 & 0.08 & 0.03 \\
\hline Constrained & $X^{2}$ & 129.33 & 117.19 & 112.97 & 146.82 & 72.93 \\
\hline \multirow[t]{3}{*}{ Group Model } & $\mathrm{DF}$ & 29 & 29 & 29 & 29 & 29 \\
\hline & CFI & 0.83 & 0.89 & 0.89 & 0.82 & 0.94 \\
\hline & RMSEA & 0.11 & 0.10 & 0.10 & 0.12 & 0.07 \\
\hline Model Differences & $X^{2}$ & $108.48 * *$ & $68.54 * * *$ & $85.08 * * *$ & $103.97 * * *$ & $53.54 * * *$ \\
\hline
\end{tabular}




\begin{tabular}{|c|c|c|c|c|c|c|}
\hline & $\mathrm{DF}$ & $*$ & 13 & 13 & 13 & 13 \\
\hline & & 13 & & & & \\
\hline \multirow[t]{2}{*}{ Path Estimate } & With $^{1}$ & $0.61 * * *$ & $0.59 * * *$ & $0.42 * * *$ & $0.54 * * *$ & $0.43^{* * *}$ \\
\hline & Without $^{2}$ & $0.35^{* * *}$ & $0.43^{* * *}$ & $0.65^{* * *}$ & $0.48^{* * *}$ & $0.47 * * *$ \\
\hline Model Characteristic & Model Fit & $\begin{array}{l}\text { Search } \\
\text { Engine }\end{array}$ & Website Content & Intranet & Internet Access & \\
\hline Unconstrained & $X^{2}$ & 41.87 & 42.18 & 33.12 & 21.39 & \\
\hline \multirow[t]{3}{*}{ Group Model } & $\mathrm{DF}$ & 16 & 16 & 16 & 16 & \\
\hline & CFI & 0.97 & 0.96 & 0.98 & 0.99 & \\
\hline & RMSEA & 0.07 & 0.07 & 0.06 & 0.03 & \\
\hline \multirow{4}{*}{$\begin{array}{l}\text { Constrained } \\
\text { Group Model }\end{array}$} & $X^{2}$ & 128.27 & 139.55 & 121.13 & 174.40 & \\
\hline & $\mathrm{DF}$ & 29 & 29 & 29 & 29 & \\
\hline & CFI & 0.88 & 0.85 & 0.88 & 0.78 & \\
\hline & RMSEA & 0.11 & 0.11 & 0.10 & 0.13 & \\
\hline \multirow[t]{2}{*}{ Model Differences } & $X^{2}$ & $86.40 * * *$ & $97.36^{* * *}$ & $88.10^{* * *}$ & $151.00 * * *$ & \\
\hline & $\mathrm{DF}$ & 13 & 13 & 13 & 13 & \\
\hline \multirow[t]{2}{*}{ Path Estimate } & With $^{1}$ & $0.47 * * *$ & $0.54^{* * *}$ & $0.75^{* * *}$ & $0.54 * * *$ & \\
\hline & Without ${ }^{2}$ & $0.57 * * *$ & $0.47 * * *$ & $0.44^{*}$ & $0.48 * * *$ & \\
\hline
\end{tabular}

Note: 1-With represents "With the particular column of IT application. 2 - Without represents "Without the particular column of IT application. ${ }^{* * *} \mathrm{p}<0.001,{ }^{* *} \mathrm{p}<0.01,{ }^{*} \mathrm{p}<0.05$.

Looking at the path estimates, all relationships are significant in both groups. As predicted, the relationship is greater for With IT application group as compared to Without IT application group except Decision Support System, Document Management and Search Engine; Without group is greater than With group. Therefore, Organisational competitive advantage is enhanced more with E-Mail, Content Management, Knowledge Base/Repository, Website Content, Intranet and Internet Access as compared to without the IT application group.

Figure 3 illustrates the types of IT applications as moderators incorporating in collaborating capability-organisational competitive advantage relationship with hypotheses numbering H2a to H2i.

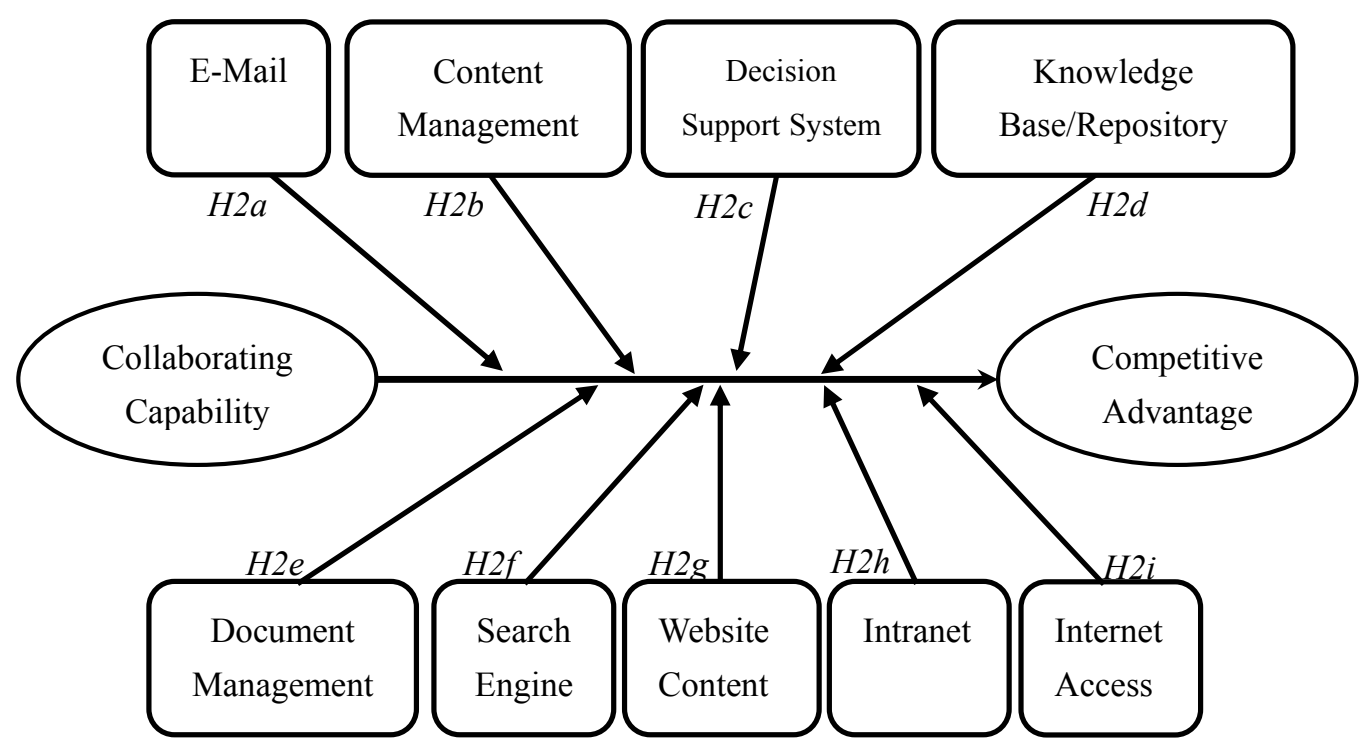

Figure 3. Moderating variables

\section{Discussion}

The collaborating capability with three components tested in CFA consists of three supported items C1, 'Provide multimedia operations and development (i.e., video conferencing)', C2, 'Provide a common system for 
document management', and C3, 'Provide a common system for members of other work groups within an organisation'. Figure 2 shows that collaborating capability with standardised regression weight of 0.46 is a strong antecedent to organisational competitive advantage ( $\mathrm{H} 1)$.

The collaborating capability is needed to achieve organisational competitive advantage. This means as organisations need collaboration capability to ensure that people are linked and communicated especially in the progressive movement of globalisation. The results are in line with other studies (Hair, Anderson, Tatham, \& Black, 1998; McNearney, 1996; Michalisn, et al., 1997; Spitzer, 1996), which noted that collaboration is an enabler of organisational learning which constitutes knowledge creation for sustainable organisational competitive advantage. Another interpretation is that strategy consulting organisations such as Bain, Boston Consulting Group and McKinsey have developed and effectively used IT applications that enhance dialogue between individuals. For instance, communities of practice, brainstorming sessions, one-on-one conversations, and apprenticeship were implemented to effectively support collaboration which enhanced knowledge creation (Hansen, Nohria, \& Tierrney, 1999).

As predicted, E-mail system emerges top moderating collaborating capability from the 22 IT applications in this study $(H 2 a)$. Many organisations use e-mail to interact with work colleagues, customers or other organisations (Debowski, 2006; Zehrer, 2011). Content and document management tools are the tools that offer abilities to integrate, classify, and codify knowledge from various sources (Benbya, et al., 2004). With this, collaborating capability is enhanced with content management tools which will then enhance organisational competitive advantage (H2e). The quality, credibility and value of the application contents need to be monitored as the contents can be drawn anywhere in the organisation if access is permitted (Debowski, 2006). Hence, a knowledge repository may also be developed to collaborate and integrate the various knowledge sources into a coordinated system where they can be readily retrieved, in line with $H 2 d$. These results supported other studies (Davenport \& Prusak, 2000; Debowski, 2006; Michalisn, et al., 1997; Nonaka, 1994) which state that the new created knowledge is stored into the corporate databases, systems and operating technologies. The stored knowledge will then further expand the corporation's intellectual assets which are needed for sustainable competitive advantage.

Search engines as moderator was supported by other studies (Alavi \& Leidner, 2001; Leistner, 2010; Tiwana, 2002). For instance, search and retrieval commands are important aspects in designing timely and easy access to organisational knowledge while avoiding a condition of information overload (H2f). Furthermore, website content was supported as moderator, supporting H2g. Ford Motor Company incorporated intensive technology-knowledge and electronic commerce system in the company's Web site to redefine the auto manufacturing industry, gain a competitive stronghold in emergent electronic markets, and to get closer to its customers. The organisation has established the "autoxchange" mart to enable consumers to get highly customised products while the organisation saves substantial amounts of capital in auto designers, financiers, marketers, and production engineers which otherwise would have cause the organisations to pay for insightful knowledge about the customers, customer needs, trends in consumer tastes and the evolution in consumer behaviour. Thus, with the website content, Ford is attempting to create a sustainable competitive advantage in the auto industry (Kerwin, 2000).

Intranet-based system greatly enhances knowledge sharing among employees throughout the world. For instance, Sharenet, a Siemens intranet-based system enables Siemens staff to share their innovative customer solutions around the world (Debowski, 2006) (H2h). Furthermore, Internet was supported as moderator (H2i). The results are supported by Meso \& Smitch (2000)'s study, which also shows that Internet enables Web browser to access knowledge resources and connects geographically-dispersed professionals. Fortune's senior editor, David Kirkpatrick, emphasised that reducing the digital divide is necessary to reduce the global economic divide at a conference held at the United Nations (Kirkpatrick, 2006). Furthermore, the use of Internet resulting in enhancement of collaborating is also supported by Debowski (2006) and Shegda (2003). Debowski (2006) proved the use of the Internet from the office desktop computer is a core function to enable access to email exchanges which can be expanded to become more effectively collaborative using various application packages. For instance, iManage's WorkSite Communication Server allows auto-routed emails to a repository for classification and filing which facilitate collaborate sharing and interaction (Shegda, 2003).

\section{Contributions to Research}

The findings of the paper contribute some key ideas to the existing literature on IT applications on collaborating capability and organisational competitive advantage, primarily for MSC Malaysia Companies, in an emerging and developing economy. The current literature and studies for the context on this paper is still scarce relative to 
the existing literature on IT applications in collaborating capability. This research represents one of the first few attempts to look into the IT applications as moderators in collaborating capability-organisational competitive advantage relationship. While previous studies demonstrated collaborating capability to have positive influence on organisational competitive advantage, the findings (Figure 2) support collaborating capability as having a direct and positive influence on organisational competitive advantage. From the theoretical perspective, the evidence of the research model developed in this research is effective for conceptualising moderating effects on IT applications collaborating capability-organisational competitive advantage relationship. At the same time, the results also provide some insights for IT practitioners and researchers who used IT applications to achieve organisational competitive advantage.

\section{Contributions to Practice}

The findings of this research will enable IT managers to invest suitable IT applications for its best use. For instance, having E-Mail, Content Management, Decision Support System, Knowledge Base/Repository, Document Management, Search Engine, Website Content, Intranet and Internet Access should be priortitised and a company having them should have a higher chance of success in achieving the organisational competitive advantage. The instruments developed in the research could also be used by IT application designers and programmers to predict if the IT applications could achieve certain levels of success among their target consumers. By knowing the suitable IT applications, they would be able to focus on the design factors with confidence of a higher probability of success.

IT applications should also provide collaboration capability which enable "linking people so that they can work together" (Kim, 2001). This feature is especially meaningful for large companies which are having their accounts online and multi-user access. Multi-users from any part of the world are allowed to access the details to enter or retrieve the required information. However, different organisations have different platforms. So it is required that the application should be compatible in various contexts for all the collaborators.

\section{Limitations of Study and Agenda for Future Studies}

Future studies can be enhanced by testing in different contexts to generalise the findings. For instance, non-MSC Malaysia companies and small and medium enterprises (SMEs) since SMEs are considered the backbone of industrial development in the country (Saleh \& Ndubisi, 2006).

IT capabilities can impact overall organisational performance either directly or indirectly (Becerra-Fernandez, Gonzalez, \& Sabherwal, 2004). Future research could target relationship on the direct impacts, such as revenues or costs, and can be explicitly linked to organisational vision and strategy.

On the other hand, future researchers could also use the types of IT applications in other studies to study any significant differences between the IT applications in different organisations (for example non-MSC Malaysia organisations).

\section{Conclusion}

A research model for IT applications as moderators for collaborating capability-organisational competitive advantage was successfully developed, assessed and validated. Direct and positive impact of collaborating capability towards organisational competitive advantage and IT applications as moderators are supported. Malaysia, an emerging country and MSC companies are the cornerstones for IT applications implementation, these findings would serve as guidelines to companies in other emerging industries on key IT applications necessary for organisational competitive advantage. Academically, rich knowledge of a set of foundation for the theory, practice and limitations of the research and the future research areas were also highlighted.

\section{References}

Alavi, M., \& Leidner, D. E. (2001). Review: Knowledge management and knowledge management systems: conceptual foundations and research issues. MIS Quarterly, 25(1), 1-30. http://dx.doi.org/10.2307/3250961

Alting, D. L., \& Jøgensen, D. J. (1993). The LifeCycle Concept as a Basis for Sustainable Industrial Production. $\begin{array}{lllll}\text { CIRP Annals } & \text { Manufacturing }\end{array}$ http://dx.doi.org/10.1016/S0007-8506(07)62417-2

Andres, H. P., \& Zmud, R. W. (2001). A contingency approach to software project coordination. Journal of Management Information Systems, 18, 41-70.

Becerra-Fernandez, I., Gonzalez, A., \& Sabherwal, R. (2004). Knowledge Management: Challenges, Solutions, and Technologies. New Jersey: Pearson Education, Inc. 
Benbya, H., Passiante, G., \& Aissa Belbaly, N. (2004). Corporate portal: a tool for knowledge management synchronization. International Journal of Information Management, 24(3), 201-220. http://dx.doi.org/10.1016/j.ijinfomgt.2003.12.012

Bhatt, G., Emdad, A., Roberts, N., \& Grover, V. (2010). Building and leveraging information in dynamic environments: The role of IT infrastructure flexibility as enabler of organizational responsiveness and competitive advantage. Information \& Management, 47(2010), 341-349. http://dx.doi.org/10.1016/j.im.2010.08.001

Bollen, K. A. (1989). Strutural Equations with Latent Variables. New York: Wiley.

Burca, S. D., Fynes, B., \& Brannick, T. (2006). The moderating effects of information technology sophistication on services practice and performance. International Journal of Operations \& Production Management 26(11), 1240-1251. http://dx.doi.org/10.1108/01443570610705845

Chang, T. C., \& Chuang, S. H. (2011). Performance implications of knowledge management processes: Examining the roles of infrastructure capability and business strategy. Expert Systems with Applications, 38(5), 6170-6178. http://dx.doi.org/10.1016/j.eswa.2010.11.053

Christopher, H. J. (2006). Knowledge management past and future. KM World, 15(1), 20.

Cooper, B. L., Watson, H. J., Wixom, B. H., \& Goodhue, D. L. (2000). Data warehousing supports corporate strategy at First American Corporation. MIS Quarterly, 24(4), 547-567. http://dx.doi.org/10.2307/3250947

Cooper, D. R., \& Schindler, P. S. (2006). Business Research Methods (9th ed.). New York: McGraw Hill.

Cuijpers, M., Guenter, H., \& Hussinger, K. (2011). Costs and benefits of inter-departmental innovation collaboration. Research Policy, 40, 565-575. http://dx.doi.org/10.1016/j.respol.2010.12.004

Czaja, R., \& Blair, J. (1996). Designing surveys: A guide to decisions and procedures. Thousand Oaks, California: Pine Forge Press.

Davenport, T. H., \& Prusak, L. (2000). Working Knowledge (Book Review) (Vol. 31).

Debowski, S. (2006). Knowledge Management. Milton, Queensland: Wiley.

Dehning, B., \& Stratopoulos, T. (2003). Determinants of a sustainable competitive advantage due to an IT-enabled strategy. Journal of Strategic Information Systems, 12(2003), 7-28. http://dx.doi.org/10.1016/S0963-8687(02)00035-5

Dunk, A. S. (2004). Product life cycle cost analysis: the impact of customer profiling, competitive advantage, and quality of IS information. Management Accounting Research, 15(4), 401-414. http://dx.doi.org/10.1016/j.mar.2004.04.001

Economic Planning Unit [EPU]. (2012, February 25). Retrieved February 25, 2012, from http://www.epu.gov.my/html/themes/epu/html/RMKE10/rmke10_english.html

Gabler, S. (1981). A comparison of Sampford's sampling procedure versus unequal probability sampling without replacement. Biometrika, 68(3), 725-727. http://dx.doi.org/10.1093/biomet/68.3.725

Galbraith, J. K. (1973). Designing Complex Organizations. Reading, Massachusetts: Addison-Wesley Longman.

Galbraith, J. K. (1974). Organization design: An information processing view. Interfaces, 4(3), 28-36. http://dx.doi.org/10.1287/inte.4.3.28

Garson, G. D. (1998). Structural Equation Modelling. Retrieved from http://www2.chass.ncsu.edu/garson/pa765/structur.htm

Grant, L. (1998, 12 January). Happy Workers - High Returns. Fortune, 81(86 paragraphs).

Hair, J. F., Anderson, R. E., Tatham, R. L., \& Black, W. C. (1998). Multivariate Data Analysis (5th ed.). New Jersey: Prentice-Hall, Inc.

Hair, J. F., Black, W. C., Babin, B. J., \& Anderson, R. E. (2010). Multivariate Data Analysis - A Global Perspective (7th ed.). New Jersey: Pearson Prentice Hall.

Hansen, M. T., Nohria, N., \& Tierrney, T. (1999). What's your strategy for managing knowledge? Harvard Business Review, 77(2), 106-118.

Joreskog, K. G., \& Sorbom, D. (1996). LISREL 8: User's Reference Guide. Chicago: Scientific Software International. 
Kerwin, K. (2000, 28 February). At Ford, E-Commerce is job 1. Business Week, 74-78.

Kim, S. K. (2001). An empirical study of the relationship between knowledge management and information technology infrastructure capability in the management consulting industry. Unpublished doctoral dissertation, University of Nebraska-Lincoln, Nebraska.

Kirkpatrick, D. (2006, 22 December ). Technology and the developing world Fortune.

Kline, R. B. (2005). Principles and Practice of Structural Equation Modeling (2nd ed.). New York: The Guilford Press.

Kline, R. B. (2009). Becoming A Behavioral Science Researcher. New York: The Guilford Press.

Leistner, F. (2010). Mastering Organizational Knowledge Flow. New Jersey: John Wiley \& Sons, Inc.

Lim, J. H., Stratopoulos, T. C., \& Wirjanto, T. S. (2012). Role of IT excecutive in the firm's ability to achieve competitve advantage through IT capability. International Journal of Accounting Information Systems, 13(2012), 21-40. http://dx.doi.org/10.1016/j.accinf.2011.07.001

McNearney, D. J. (1996). Employee Motivation: Creating A Motivated Workforce. HR Focus, 1-6.

Meso, P., \& Smith, R. (2000). A resource-based view of organizational knowledge management systems. Journal of Knowledge Management, 4(3), 224-234. http://dx.doi.org/10.1108/13673270010350020

Michalisn, M., Smith, R., \& Kline, D. (1997). In Search of Strategic Assets. International Journal of Organizational Analysis, 5(4), 360-387. http://dx.doi.org/10.1108/eb028874

Minkyun, K. (2010). Impact of Strategic Sourcing, E-Procurement and Integration on Supply Chain Risk Mitigation and Performance. The State University of New York.

Ngai, E. W. T., \& Chan, E. W. C. (2005). Evaluation of knowledge management tools using AHP. Expert Systems with Applications, 29(4), 889-899. http://dx.doi.org/10.1016/j.eswa.2005.06.025

Niels, J. B. (2008). Introduction to Structural Equation Modelling Using SPSS and AMOS. London: SAGE Publications Ltd.

Nilsson, L., Johnson, M. D., \& Gustafsson, A. (2001). The impact of quality practices on customer satisfaction and business results: product versus service organizations. Journal of Quality Management, 6(1), 5-27. http://dx.doi.org/10.1016/S1084-8568(01)00026-8

Nonaka, I. (1994). A Dynamic Theory of Organizational Knowledge Creation. Organization Science, 5(1), 14-37. http://dx.doi.org/10.1287/orsc.5.1.14

Paul, P. T. (2008). Inside the adaptive enterprise: an information technology capabilities perspective on business process agility. Inf Technol Manage, 9(1), 21-36. http://dx.doi.org/10.1007/s10799-007-0024-8

Perera, M. U. S. (2012). DecisionMaking Delays with Regard to IT Investments. Procedia Social and Behavioral Sciences, 40(2012), 258-263. http://dx.doi.org/10.1016/j.sbspro.2012.03.188

Premkumar, G., Ramamurthy, K., \& Saunders, C. S. (2005). Information processing view of organizations: An exploratory examination of fit in the context of interorganizational relationships. Journal of Management Information Systems, 22(1), 257-294.

Qi, X., Lan, B., \& Guo, Z. (2008). Conceptual Model of IT Infrastructure Capability and Its Empirical $\begin{array}{lllll}\text { Justification. Tsinghua Science } \quad \& \quad \text { Technology, } & \text { 13(3), }\end{array}$ http://dx.doi.org/10.1016/S1007-0214(08)70062-2

Rao, B., Navoth, Z., \& Horwitch, M. (1999). Building a world class logistics, distribution and electronic commerce infrastructure. Electronic Markets, 9(3), 174-180. http://dx.doi.org/10.1080/101967899359076

Reed, R., Lemak, D. J., \& Mero, N. P. (2000). Total quality management and sustainable competitive advantage. Journal of Quality Management, 5(1), 5-16. http://dx.doi.org/10.1016/S1084-8568(00)00010-9

Sala-I-Martin, X., Bilbao-Osorio, B., Blanke, J., Hanouz, M. D., \& Geiger, T. (2011). The Global Competitiveness Index 2011-2012. Geneva, Switzerland: World Economic Forum.

Salant, P., \& Dillman, D. A. (1994). How to conduct your own survey. New York: Wiley.

Saleh, A. S., \& Ndubisi, N. O. (2006). An Evaluation of SME Development in Malaysia. International Review of Business Research Papers, 2(1), 1-14.

Sekaran, U. (2003). Research Methods for Business: A Skill Building Approach (4th ed.). New Jersey: John 
Wiley \& Sons, Inc.

Shegda, K. (2003). iManage WorkSite integrated document management and collaboration suite (No. DPRO-91219): Gartner Product Report.

Spitzer, D. R. (1996). Rewards That Really Motivate. Management Review, 85(5), 45-50.

Tiwana, A. (2002). The knowledge management toolkit: orchestrating IT, strategy, and knowledge platforms (2nd ed.). New Jersey: Prentice Hall PTR.

Tseng, M. L. (2010). An assessment of cause and effect decision-making model for firm environmental knowledge management capacities in uncertainty. Environmental Monitoring and Assessment, 161(1-4), 549-564. http://dx.doi.org/10.1007/s10661-009-0767-2

Wang, E., Klein, G., \& Jiang, J. J. (2007). IT Support in Manufacturing Firms for a Knowledge Management Dynamic Capability Link to Performance. International Journal of Production Research, 45(11), 2419-2434. http://dx.doi.org/10.1080/00207540601020437

Wiengarten, F., Humphreys, P., Cao, G., Fynes, B., \& McKittrick, A. (2010). Collaborative supply chain practices and performance: exploring the key role of information quality. Supply Chain Management, 15(6), 463-473. http://dx.doi.org/10.1108/13598541011080446

World Bank. (2012, May 15). Malaysia Overview. Retrieved May 15, 2012, from http://www.worldbank.org/en/country/malaysia/overview

Zehrer, A. (2011). Knowledge management in tourism-the application of Grant's knowledge management model to Austrian tourism organizations. Tourism Review of AIEST-International Association of Scientific Experts in Tourism, 66(3), 50-64. http://dx.doi.org/10.1108/16605371111175320

\section{Copyrights}

Copyright for this article is retained by the author(s), with first publication rights granted to the journal.

This is an open-access article distributed under the terms and conditions of the Creative Commons Attribution license (http://creativecommons.org/licenses/by/3.0/). 